\title{
Responses of Single Neurons in the Toad's Caudal Ventral Striatum to Moving Visual Stimuli and Test of Their Efferent Projection by Extracellular Antidromic Stimulation/Recording Techniques
}

\author{
H. Buxbaum-Conradi J.-P. Ewert \\ Abteilung Neurobiologie, Fachbereich Biologie/Chemie, Universität Kassel (GhK), Kassel, Germany
}

\author{
Key Words \\ Toad - Amphibian - Anuran - Anamniote - Vision • \\ Prey-catching $\cdot$ Striatum • Optic tectum
}

\begin{abstract}
Previous work in anuran amphibians has shown that activity in the caudal ventral striatum correlates with visuomotor activity: orienting responses toward prey fail to occur after striatal lesions. Thus it has been suggested that the striatum influences visually guided behavior. Therefore, the present study investigates visual response properties from neurons recorded in the striatum. Extracellular recordings of 104 single neurons of the cane toad's (Bufo marinus) caudal ventral striatum (STR) reveal five different response properties: resting discharge activity uninfluenced by the visual test stimuli (group STR1, 24.0\%); resting discharge activity increased by any moving visual object (STR2, 31.7\%); preference to moving compact objects (STR3, 15.4\%); preference to certain configurational moving objects (STR4a and b, $13.5 \%)$, and resting activity reduced by visual stimuli (STR5, 15.4\%). The receptive fields of these neurons encompassed the contralateral $(46 \%)$ or the entire field of vision (54\%). Of the neurons recorded in the striatum, $34 \%$ responded to electrical stimuli applied in the rostral diencephalon to the ipsilateral lateral forebrain bundle (LFB) which connects the striatum with the optic tectum (e.g. either directly or via pretectum or tegmentum). Various electrically driven STR neurons (40\%) have axons
\end{abstract}

that project caudally through the LFB, which was suggested by their antidromic activation in response to electrical stimuli applied to the LFB in the rostral diencephalon. In the present study, the main striatal output is mediated by 'motion detectors' (STR2) and 'compact object perceivers' (STR3). It is suggested that the caudal ventral striatum is involved in visual attentional processes that allow the translation of perception into action.

Copyright $\AA^{\circledR} 2000$ S. Karger AG, Basel

\section{Introduction}

In amphibians, the optic tectum constitutes a main retinorecipient processing structure that is essential for the release of visually guided behaviors such as prey-catching and predator avoidance [e.g. Székely and Lázár, 1976; Ingle, 1983; Ewert, 1987; Weerasuriya, 1989]. The forebrain is involved in modulating, specifying, and gating visual stimulus responses [Ewert, 1984, 1992, 1997; Patton and Grobstein, 1998a, b]. Various retino-recipient diencephalic structures (i.e. anterior thalamic and pretectal thalamic nuclei), the lateral thalamic nucleus, and tegmental structures mediate tectal and telencephalic information flow [Lázár, 1971; Fite and Scalia, 1976; Wilczynski and Northcutt, 1977, 1983a, b; Neary and Northcutt, 1983; Marín et al., 1997a]. The question of how the telencephalon controls retino-tectal information processing is a theme of our current research [Ewert et al., 1999].

\begin{tabular}{ll}
\hline KARGER & ( ) 2000 S. KargerAG, Basel \\
Fax +41 61 306 12 34 & 0006-8977/99/0546-0338\$17.50/0 \\
$\begin{array}{l}\text { E-Mail karger@ karger.ch } \\
\text { www.karger.com }\end{array}$ & $\begin{array}{l}\text { Accessible online at: } \\
\text { www.karger.com/journals/bbe }\end{array}$
\end{tabular}

Prof. Dr. J.-P. Ewert

Abteilung Neurobiologie, Fachbereich Biologie/Chemie

Universität Kassel (GhK), D-34132 Kassel (Germany)

Fax +49-561-804-4146

E-Mail ewertjp@aol.com 
Lesion studies have shown that the telencephalon influences the visual release of prey-catching behavior. After ablation of both telencephalic hemispheres in toads or frogs, visually mediated prey orienting behavior failed to occur; unilateral telencephalic ablation led to a neglect of prey moving in the visual field of the contralateral eye [Ewert, 1967, 1984; Patton and Grobstein, 1998a]. As small lesions to the toad's or frog's caudal ventral striatum also showed this effect [Finkenstädt, 1989; Patton and Grobstein, 1998b], it has been concluded that the visual release of prey oriented behavior depends on stimulating striatal areas that modulate tectal motor output [see also Ewert, 1992, 1997; Marín et al., 1998a, b]. Birkhofer et al. [1994] provided evidence that the striatum of the clawed toad (Xenopus laevis) is also involved in the processing of mechanosensory and acoustic information as well as in multisensoric interaction, thus supporting the hypothesis that this structure mediates attentional processes.

Neuroanatomical studies showed that the amphibian striatum obtains afferent visual input from the tectum relayed by the lateral thalamic nucleus and the pretectal caudal thalamus [Gruberg and Ambros, 1974; Northcutt and Kicliter, 1980; Vesselkin et al., 1980; Wilczynski and Northcutt, 1983a]. Axons of striatal efferent neurons travel in the lateral forebrain bundle (LFB) to the tectum either directly [Finkenstädt et al., 1983; Marín et al., 1997c] or indirectly, via pretectal or tegmental nuclei [Vesselkin et al., 1980; Wilczynski and Northcutt, 1983b; Lázár and Kozicz, 1990; Marín et al., 1997a, c]. A trisynaptic striato-pallidopretecto-tectal pathway also exists [Marín et al., 1998b]. The presence of many different routes that relate striatal influences to tectal neurons suggests a complex system by which tecto-motor functions can be influenced. Wilczynski and Northcutt [1983b] put forward the notion that in anuran amphibians 'the extensive interconnections between the basal ganglia and the midbrain roof in these animals suggests that a major output of the amphibian forebrain may be involved in the organization of multimodal sensory information into meaningful attentional behavior and the modulation of the appropriate orientation to this information'. The anuran striatum is homologous to a portion of the amniote basal ganglia [Wilczynski and Northcutt, 1983b; Reiner et al., 1984; Marín et al., 1997a-e] which in mammals is known to be involved in initiating or controlling orientational and attentional responses [e.g. Hore and Vilis, 1980; Chevalier et al., 1984; Chevalier and Deniau, 1990].

In the present investigation, we quantitatively analyze the properties of spiking neurons recorded from the caudal ventral striatal region in response to various kinds of visual stimuli. Furthermore, we check efferent projections of these neurons by their antidromic activation to electrical stimuli applied to the ipsilateral LFB in the rostral diencephalon.

\section{Materials and Methods}

\section{Experimental Animals}

The experimental animals were South American cane toads (Bufo marinus) kept in an amphibian room at a temperature of $21^{\circ} \mathrm{C}$, a relative humidity of 70-90\%, and a constant day(12 h)/night(12 h) cycle. Several vivaria measuring $97 \times 60 \times 30 \mathrm{~cm}^{3}$ in size, accommodated about 6 toads each. A portion of wet soft-foamed plastic material covered two-thirds of the vivarium floor. The remaining part was filled with water and served as a pool area. Stones and pieces of bark offered the toads shelter. The usual feeding rate was once per week. Toads received mealworms which had been fed with Altromin ${ }^{\circledR}$, a mouse food enriched with vitamins and trace elements.

\section{Presentation of Visual Stimuli}

Visual stimuli were presented to the toad's eye that had been centered in a perimetric apparatus [Ewert and Borchers, 1971] (fig. 1A). Stimuli of black cardboard moved against a homogeneous white background (contrast 0.95 ) in a horizontal direction (from left to right or vice versa) at a visual angular velocity of $8 \% \mathrm{sec}$ and at a distance of $25 \mathrm{~cm}$ from the toad's eyes. We used the following 4 standard test stimuli: (1) a $2 \times 16^{\circ}$ rectangular bar whose longer axis was oriented parallel to the direction of movement was called $\mathrm{W}$ [orm]-configuration ( $\mathrm{W}_{16^{\circ}}$ stimulus); (2) a $2 \times 16^{\circ}$ bar whose longer axis was oriented perpendicular to the direction of movement called $\mathrm{A}$ [ntiworm]-configuration ( $\mathrm{A}_{16^{\circ}}$ stimulus); (3) a square measuring $4 \times 4^{\circ}\left(\mathrm{S}_{4^{\circ}}\right.$ stimulus) or $16 \times 16^{\circ}\left(\mathrm{S}_{16^{\circ}}\right.$ stimulus $)$ in size; (4) a Julesz texture $(\mathrm{JT})$ of $60 \times 60^{\circ}$ with rectangular black and white patches in random distribution (pixel size $\left.0.7^{\circ}\right)$. The $\mathrm{S}_{4^{\circ}}$ and $\mathrm{W}_{16^{\circ}}$ stimuli resembled features of prey objects, whereas $\mathrm{S}_{16^{\circ}}$ and $\mathrm{A}_{16^{\circ}}$ stimuli resembled features of predators or threatening objects. We separated the tests that used different stimuli by 1-min recovery pauses. A phototransistor registered the onset and offset of the stimulus movement and the changes in the diffuse illumination at light OFF and light ON.

\section{Preparation}

The experimental animal was anesthetized by intralymphatic administration of Ketavet ${ }^{\circledR}$ (100 mg/kg body weight). A small segment of skin and cranium of the dorsal skull were surgically removed in a region dorsal to the caudal telencephalon and the rostral diencephalon. We exposed the dorsal brain surface in this region by carefully retracting the dura mater and protecting the surface with a drop of clean mineral oil. During the recording experiment, the animal was lightly immobilized by intralymphatic injection of alpha-tubocurarine (4 mg/kg b.wt.). We covered the toad's body with a thin wet paper tissue to maintain the skin respiration and an adequate oxygen level in the immobilized animals.

The experiments comply with the 'Principle of animal care', publication No. 85-23, revised 1985 of the National Institutes of Health and also with the laws of the Federal Republic of Germany in which the experiments were performed.

\section{Electrophysiology}

We applied standard extracellular stimulation and recording techniques. Because these were extracellular recording techniques, we 


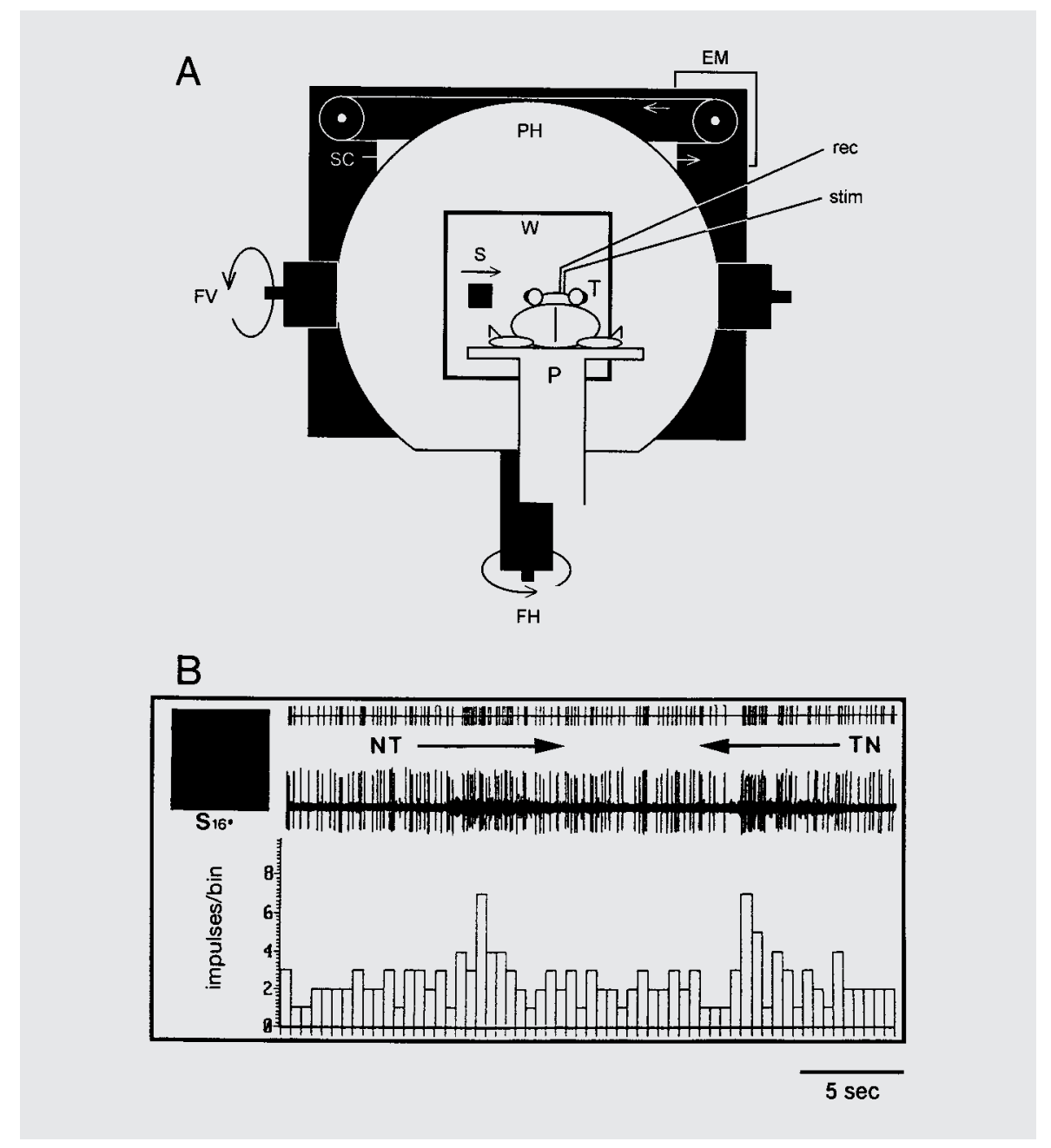

Fig. 1. A Schema showing the perimetric device for the presentation of moving visual stimuli to the immobilized toad. EM = Electric motor; $\mathrm{FH}=$ frame for horizontal adjustments of the perimetric hemisphere $(\mathrm{PH})$; $\mathrm{FV}=$ frame for vertical adjustments of the $\mathrm{PH} ; \mathrm{P}=$ podest $;$ rec $=$ recording electrode; stim = stimulation electrode; $\mathrm{S}=$ stimulus; $\mathrm{SC}=$ stimulus carrying device; $\mathrm{T}=$ toad $; \mathrm{W}=$ window of the perimeter. B Example of a spike train analysis with the signal analyzing software Spike 2; top = spike pattern of a single neuron extracted from the original record (middle); bottom $=$ histogram of the extracted neuron showing the average discharges per bin (bin width: $0.5 \mathrm{sec}$ ). This neuron (of group STR3) showed resting discharge activity which was increased by a moving $S_{16^{\circ}}$ stimulus; $\mathrm{NT}, \mathrm{TN}=$ nasotemporal and temporonasal movement of the stimulus, respectively; visual angular velocity $\mathrm{v}=8 \% \mathrm{sec}$.

could not completely eliminate the possibility that some of the recordings were from axons passing through the striatum. However, for reasons presented in the discussion, we believe this to be unlikely. We will refer to the recorded neurons as 'striatal neurons' throughout the paper.

Stainless steel needles served as recording electrodes. They were electrolytically sharpened to a tip of 2-3 $\mu \mathrm{m}$ diameter and insulated (except for the bare tip) by means of Insl-x lacquer. Electrodes were checked for impedance $(2-10 \mathrm{M} \Omega, 1 \mathrm{kHz})$ and galvanic properties [Schürg-Peiffer et al., 1993]. The recording electrode was advanced with the aid of a micromanipulator close to a cell in the caudal striatum (fig. 2C). The extracellularly recorded action potentials preamplified by a high impedance differential amplifier (Burr Brown INA 110BG) were transmitted to a storage oscilloscope (Tektronix 5113) and from its vertical output stored on a VHS video tape (JVC HR D300 EG) after digital pulse code modulation (JVC-VP-100 Digital Audio Processor). We processed the data on a 486 PC by means of a CED 1401-plus interface (Cambridge Electronic Design). For spike train analysis, the band pass filters were set at 0.3 and $1 \mathrm{kHz}$. In multiple unit records, the spike pattern of a single neuron was extracted by wave form analysis using the CED-internal programmable signal analyzing software Spike-2
(Vers. 3.19). The spike train analysis usually showed that a unit of several neurons of the same characteristic contributed to the firing pattern. Only one neuron per record and recording site was extracted and considered for spike train analysis (example is shown in fig. 1B).

Fig. 2. A Dorsal view of the toad's brain showing the arrangement of the recording electrode (rec) and the stimulation electrode (stim). a-c, levels of telencephalic transverse sections. The horizontal arrow points to the level of the diencephalic transverse section shown in B. B Localization of the pair of bipolar stimulation electrodes (see solid vertical arrows) around the lateral forebrain bundle, LFB (see upward pointing arrow) at diencephalic level, reconstructed with the Prussian Blue reaction in a Nuclear Fast Red counterstained transverse section. C Examples of reconstructed recording sites of visually sensitive striatal neurons projected at Klüver Barrera-stained transverse sections through the caudal telencephalon at the levels $\mathbf{a}-\mathbf{c}$ indicated in $\mathbf{A}$. The symbols refer to neurons of group STR2 (+), STR3 (o), and STR4 (*). Calibration bars: $500 \mu \mathrm{m}$. 

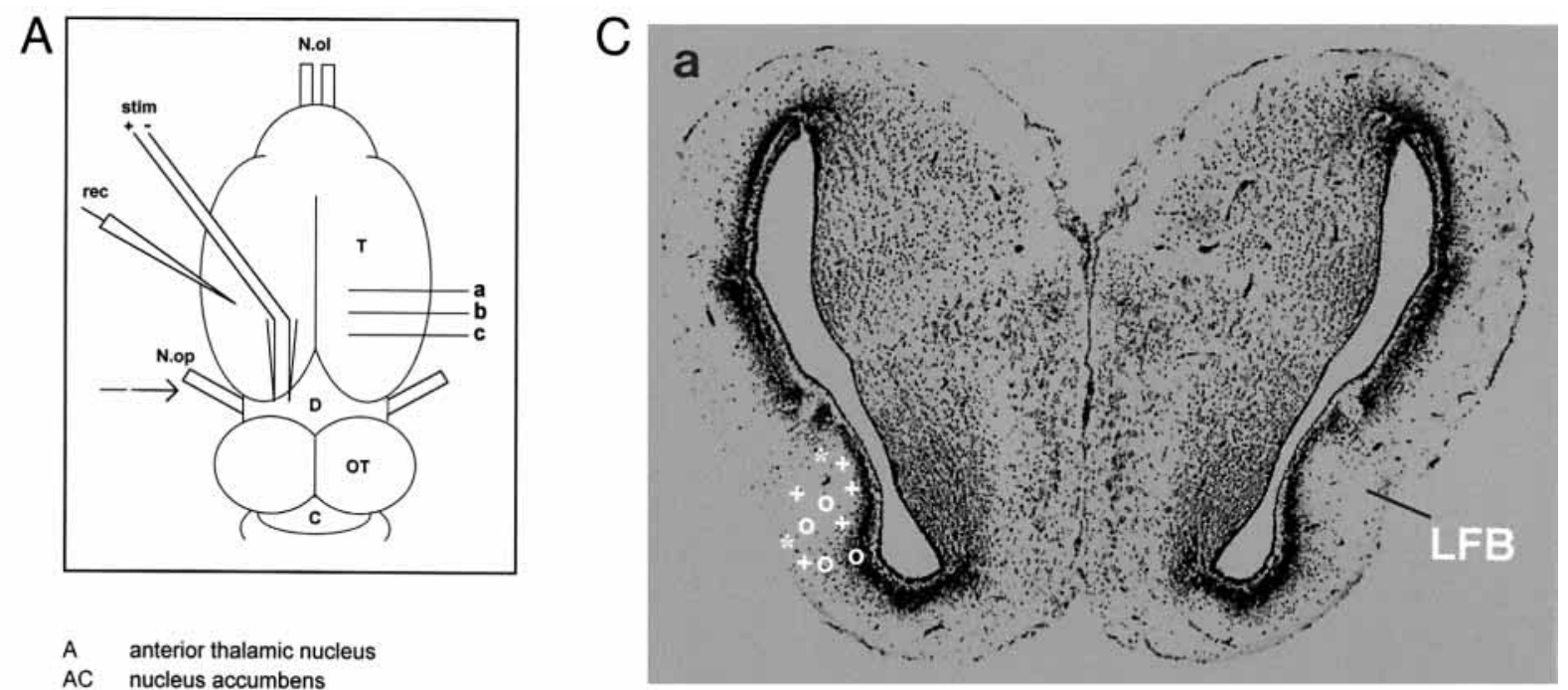

$\begin{array}{ll}\text { A } & \text { anterior thalamic nucleus } \\ \text { AC } & \text { nucleus accumbens } \\ \text { a-c } & \text { levels of transverse sections } \\ \text { C } & \text { cerebellum } \\ \text { CO } & \text { optic chiasm } \\ \text { D } & \text { diencephalon } \\ \text { dMP } & \text { dorsal medial pallium } \\ \text { DP } & \text { dorsal pallium } \\ \text { dSTR } & \text { caudal dorsal striatum } \\ \text { LA } & \text { lateral thalamic nucleus } \\ \text { LFB } & \text { lateral forebrain bundle } \\ \text { LP } & \text { lateral pallium } \\ \text { LS } & \text { lateral septum } \\ \text { M } & \text { medial thalamic nucleus } \\ \text { MS } & \text { medial septum } \\ \text { N.ol } & \text { olfactory nerve } \\ \text { N.op } & \text { optic nerve } \\ \text { OT } & \text { optic tectum } \\ \text { PO } & \text { preoptic area } \\ \text { reC } & \text { recording electrode } \\ \text { stim } & \text { stimulation electrode } \\ \text { T } & \text { telencephalon } \\ \text { VL } & \text { ventrolateral thalamic nucleus } \\ \text { VM } & \text { ventromedial thalamic nucleus } \\ \text { VMP } & \text { ventral medial pallium } \\ \text { vSTR } & \text { caudal ventral striatum }\end{array}$

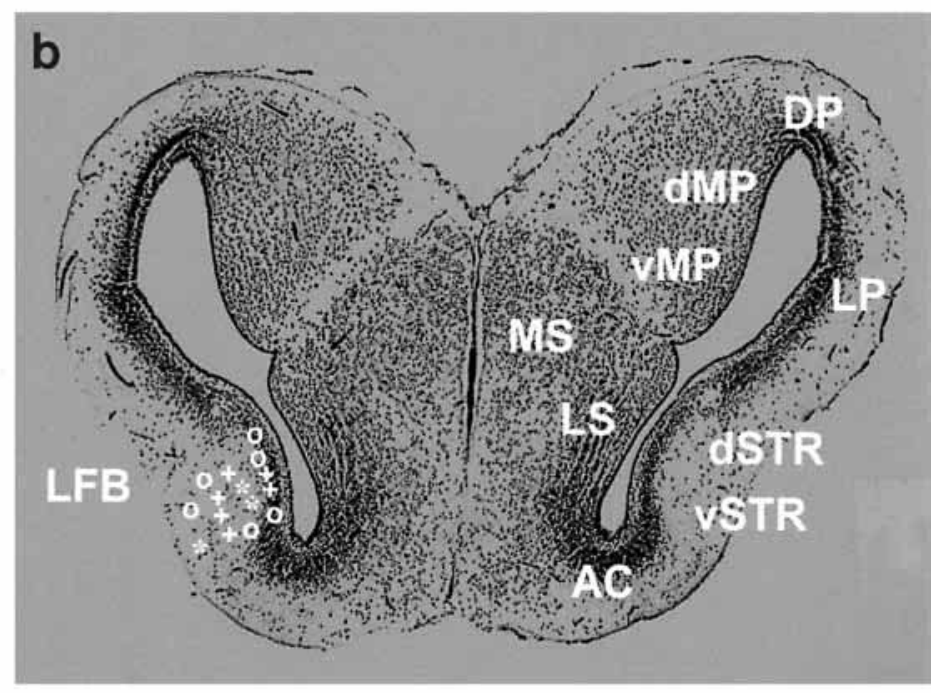

\begin{abstract}
+ STR2 neurons
- STR3 neurons

* STR4 neurons
\end{abstract}

B

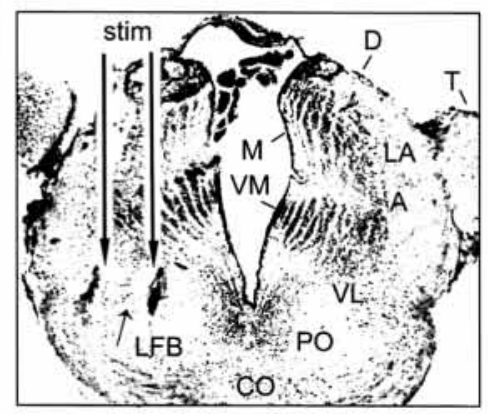

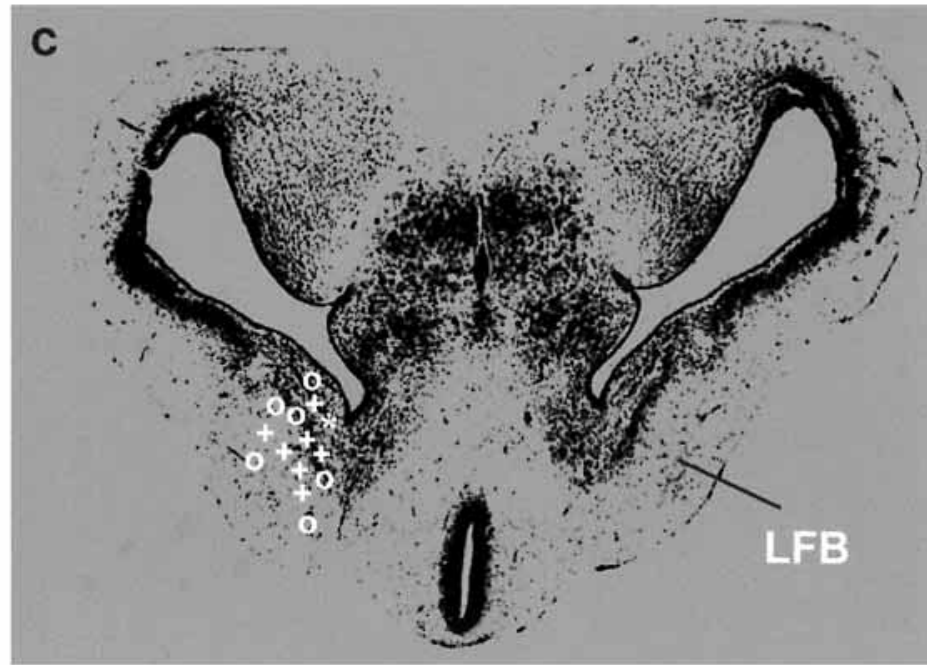


To determine whether the axon of a neuron recorded in the striatum travels in the LFB, we applied the antidromic electro-stimulation/ recording technique. After characterizing an isolated neuron (according to the criteria listed below), its action potential triggered a square wave generator (HSE-T stimulator with isolation unit) to deliver a pulse of $0.1 \mathrm{~ms}$ duration and of less than $15 \mu \mathrm{A}$. The electrical stimulus was applied in the rostral diencephalon by means of bipolar stainless steel electrodes to the ipsilateral LFB in which the descending axon of the recorded neuron travels (fig. 2A, B). Both stimulation electrodes were insulated except for the sharpened tips (exposed tip length: $100-150 \mu \mathrm{m}$; separation of both tips: less than $500 \mu \mathrm{m})$. The criteria for antidromic activation were: (1) constant latency (L), (2) ability to follow electrical impulses of relatively high frequency and (3) collision test [Fuller and Schlag, 1976]. To determine the absolute refractory period $(\mathrm{R})$, two square wave generators with isolation units generated two sequential electrical stimuli e1 and e2 (cf. fig. 8Aa), whereby e2 followed e1 after a variable interval (stimulator-1 triggered stimulator2 via a time circuit)

The collision test provided proof as to whether a recorded neuron was backfired by the electrical stimulation to LFB. In this test an orthodromic travelling spike v, recorded from a visually excited striatal neuron, triggered two sequential electrical stimuli e $1 *-\mathrm{e} 2 *$ of the types used above. Both stimuli, separated by a constant interval $(>2 R)$, elicited antidromic spikes a1* and a $2 *$, respectively. The delay between $\mathrm{v}$ and the first electrical impulse $\mathrm{e}{ }^{*}$ was varied. In the collision case, at a critical delay the orthodromic spike $\mathrm{v}$ and the antidromic spike a ${ }^{*}$ were traveling along the same axon toward each other and collided. On the storage oscilloscope screen the antidromic spike a ${ }^{*}$ in response to e $1 *$ was extinguished (cf. fig. $8 \mathrm{Ac}$ ), but not a $2 *$ in response to e $2 *$; the latter result served as a control. The empirical critical delay is $\mathrm{C}_{\mathrm{E}}$, the theoretical value $\mathrm{C}_{\mathrm{T}}=\mathrm{L}+\mathrm{R}$, and the collision error $E_{C}=C_{T}-C_{E}$. The collision criterion is still satisfied if $\left(E_{C} / C_{T}\right)<0.5$ [Fuller and Schlag, 1976].

\section{Response Criteria}

We examined the response properties of neurons recorded in the striatum according to the criteria applied previously to pretectal thalamic TH-type and tectal T-type neurons [Ewert, 1971, 1984; BuxbaumConradi and Ewert, 1995]. These criteria were: (1) size and location of a neuron's visual (excitatory) receptive field $[(\mathrm{E}) \mathrm{RF}]$ measured with a $4^{\circ}$ black square moved manually by means of a transparent stick against a white background; (2) mono- or binocularity, investigated in uncertain cases by carefully covering one eye of the toad; (3) resting discharge properties; (4) OFF/ON responses to rapid changes in the diffuse illumination of the visual field; (5) neural discharge activity in response to moving test stimuli, $\mathrm{S}_{4^{\circ}}, \mathrm{S}_{16^{\circ}}, \mathrm{W}_{16^{\circ}}, \mathrm{A}_{16^{\circ}}$, and JT, respectively, and discharge activity in the absence of visual stimuli in a bright environment as the control experiment, C; (6) responses to repetitive stimulation for a test of habituation phenomena; (7) test of directional sensitivity to nasotemporal (NT) or temporonasal (TN) stimulus movement; and (8) antidromic responses to electrical stimuli applied to the ipsilateral LFB in the rostral diencephalon.

\section{Histology}

The site of the stainless steel recording electrode (fig. 2Ca-c) was marked by passing an anodal direct current of $15 \mu \mathrm{A}$ through the electrode for a duration of $9 \mathrm{sec}$. To mark the site of a stainless steel stimulating electrode, we passed an anodal direct current of $50 \mu \mathrm{A}$ through each electrode of the electrode pair successively for a duration of $3 \mathrm{sec}$ (fig. 2B). The toad was sacrificed by intralymphatic administration of
Table 1. Neurons of the groups STR1-STR5 and their responses to electrical stimuli applied to the LFB at diencephalic level

\begin{tabular}{lrrrrrr}
\hline STR & 1 & 2 & 3 & $4 a$ & $4 b$ & 5 \\
\hline $\mathrm{n}$ & 25 & 33 & 16 & 6 & 8 & 16 \\
$\mathrm{n}_{\mathrm{LFB}}$ & - & 14 & 10 & - & 4 & 7 \\
$\mathrm{n}_{\mathrm{L}(\mathrm{v})}$ & - & 7 & 3 & - & 2 & 2 \\
$\mathrm{n}_{\mathrm{L}(\mathrm{c})}$ & - & 7 & 7 & - & 2 & 5 \\
$\mathrm{n}_{\mathrm{Ct}}$ & - & 7 & 4 & - & 1 & 2 \\
\hline
\end{tabular}

$\mathrm{n}=$ Number of neurons assigned to a group; $\mathrm{n}_{\mathrm{LFB}}=$ number of neurons responding to LFB stimulations; $\mathrm{n}_{\mathrm{L}(\mathrm{v})}=$ number of neurons showing to LFB stimulation response latencies that were variable and relatively long; $\mathrm{n}_{\mathrm{L}(\mathrm{c})}=$ number of neurons showing to LFB stimulation response latencies that were constant and short; $\mathrm{n}_{\mathrm{Ct}}=$ number of neurons fulfilling the collision-test criterion.

n overdose of Ketavet ${ }^{\circledR}$. After removing the brain and preparing it for histology, the electrolytic deposit of iron ions (from recording and stimulating electrodes) in the brain tissue was stained by means of the Prussian Blue reaction and counterstained using Nuclear Fast Red (fig. 2B). The recording sites were assigned to brain transverse sections stained with the Klüver Barrera method (fig. 2Ca-c).

\section{Statistics}

The first four responses (discharge rates) of a neuron to the same stimulus moving alternately in NT or TN direction were averaged. The mean responses to the different visual test stimuli $\left(\mathrm{S}_{4^{\circ}}, \mathrm{S}_{16^{\circ}}, \mathrm{W}_{16^{\circ}}, \mathrm{A}_{16^{\circ}}\right.$, or JT) and to the control (C) of $\mathrm{n}$ different single neurons belonging to the same response type (STR group) were calculated. In figure 7 the mean response values with their standard deviations $( \pm$ SDM $)$ are shown for neurons of the visually sensitive groups STR2-STR5. Applying the SPSS ${ }^{\circledR}$ software for statistical analysis, we performed separate one-way ANOVAs for the responses to the test stimuli and the control measured in each STR group, following the Levene-test of homogenity of variances. Normal distributions were calculated using Blom's proportional estimation formula and the 'normal P-P plot' routine. For the multiple comparisons of the mean responses to each test stimulus and to the control in a STR group, Bonferroni's post-hoc test was applied (table 2).

\section{Results}

\section{General Survey}

Altogether, 128 neurons recorded from the caudal ventral striatal region were investigated in this study. To analyze the resting discharge properties and responses to visual stimuli, we assigned 104 neurons to five main groups: (1) STR1 neurons showing resting discharges that were not influenced by the visual test stimuli; (2) STR2 neurons responding to any moving visual stimulus without differentiation among the 


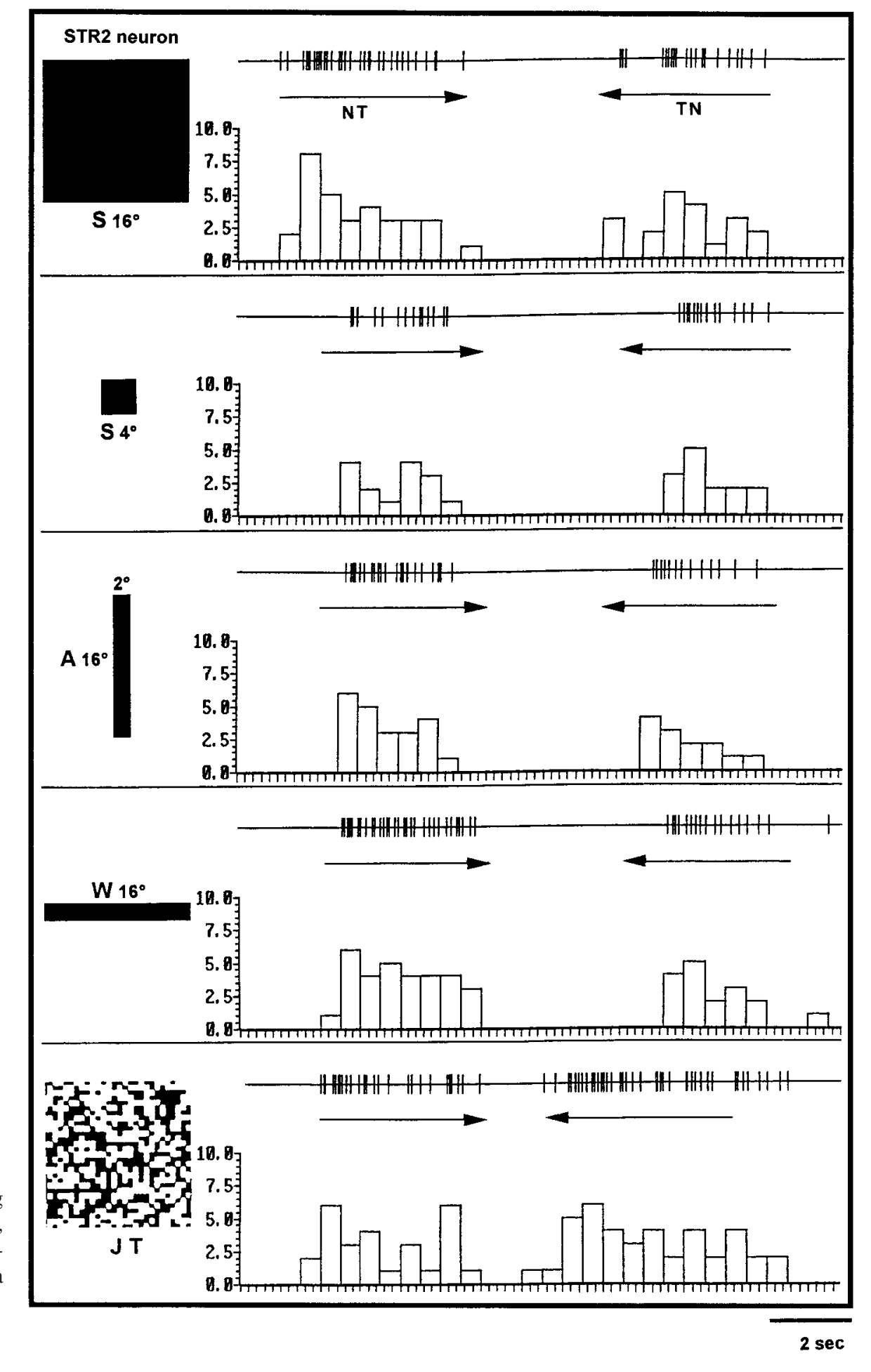

Fig. 3. Neuron of group STR2 discharging in response to any moving stimulus $\left(\mathrm{S}_{16^{\circ}}, \mathrm{S}_{4^{\circ}}\right.$, $\mathrm{W}_{16^{\circ}}, \mathrm{A}_{16^{\circ}}$, or JT) and showing no significant object preference, thus behaving like a 'motion detector'; bin width: $0.5 \mathrm{sec}$. 
test stimuli; (3) STR3 neurons preferentially responding to compact (square) stimuli vs. configurational (bar) stimuli; (4) STR4 neurons displaying variable sensitivity to moving configurational stimuli; (5) STR5 neurons whose resting discharge activities were reduced by visual stimulation.

In the tests of antidromic activation (table 1), 35 neurons responded to repetitive electrical stimuli applied to the ipsilateral LFB in the rostral diencephalon. In 14 neurons the response latencies were relatively long and variable. The remaining 21 neurons showed short, stable, latencies of $\mathrm{L}=$ $2.2 \pm 0.4(\mathrm{SDM}) \mathrm{msec}$. In 14 cells recorded in the striatum, the antidromic activation and suggested axonal projections caudally through the LFB was shown by means of the collision test at a collision interval of $C_{E}=6.4 \pm 0.9 \mathrm{msec}$. In these cases, the neurons followed electrical stimuli at $217 \mathrm{~Hz}$.

\section{STRl Neurons}

The resting discharge activities of these neurons $(n=25)$ were not influenced by the visual test stimuli. In 14 neurons, the spike activity was rather regular at 1-2 spikes/sec; 6 neurons showed spontaneous trains, and 5 neurons were characterized by irregularly occurring brief spike trains (bursts) with peak frequencies of 20 spikes/sec and interburst intervals up to $90 \mathrm{sec}$. These neurons did not respond to LFB stimulation.

\section{STR2 Neurons}

Neurons of this group $(n=33)$ showed either weak or no resting discharges. However, they responded well to any moving visual stimulus. No strong preference to any particular test stimulus size or orientation was observed: $\mathrm{S}_{16^{\circ}}=$ $\mathrm{W}_{16^{\circ}}=\mathrm{A}_{16^{\circ}}=\mathrm{S}_{4^{\circ}}>\mathrm{C}$ (fig. 3). Thus, motion was the critical cue. (For quantitative data see fig. 7 , for statistical evaluation see table 2.) These neurons showed no habituation to repetitive stimulation and the moving Julesz texture (JT) elicited only moderate responses. There was no selectivity to stimulus movements in either the nasotemporal or temporonasal direction. Changes in diffuse light elicited brief bursts of spikes which were stronger to light OFF than to light ON. The ERF of the neurons encompassed the entire visual field of the contralateral eye. When the LFB was stimulated, 7 neurons responded with long latencies of 8-34 msec; 7 other neurons satisfied the collision criterion: $\mathrm{C}_{\mathrm{E}}=6.7 \pm 0.5 \mathrm{msec}$ at $\mathrm{L}=2.4 \pm 0.3 \mathrm{msec}$ and $\mathrm{R}=4.8 \pm$ $0.5 \mathrm{msec}$ (table 1; an example is shown in fig. $8 \mathrm{Cc}$ ).

\section{STR3 Neurons}

The resting discharge rates of these neurons $(n=16)$ were increased by compact moving squares $\left(S_{4^{\circ}}\right.$ or $\left.S_{16^{\circ}}\right)$, but
Table 2. Statistical evaluation of the preferences of visually sensitive neurons of the groups STR2-STR5 to the test stimuli $\mathrm{S}_{4^{\circ}}, \mathrm{S}_{16^{\circ}}, \mathrm{W}_{16^{\circ}}$, and $\mathrm{A}_{16^{\circ}}$, and to the control $\mathrm{C}$

\begin{tabular}{|c|c|c|}
\hline Group & $\mathrm{n}$ & Stimulus preferences \\
\hline STR2 & 33 & $\begin{array}{r}p<0.001 \\
\mathrm{~S}_{16^{\circ}}=\mathrm{W}_{16^{\circ}}=\mathrm{A}_{16^{\circ}}=\mathrm{S}_{4^{\circ}}>\mathrm{C}\end{array}$ \\
\hline STR3 & 16 & $\begin{array}{c}p<0.001 \\
\mathrm{~S}_{16^{\circ}}=\mathrm{S}_{4^{\circ}}>\mathrm{A}_{16^{\circ}}=\mathrm{W}_{16^{\circ}}=\mathrm{C}\end{array}$ \\
\hline STR4a & 6 & $\begin{array}{c}p<0.001 \\
\mathrm{~S}_{16^{\circ}}=\mathrm{A}_{16^{\circ}}>\mathrm{W}_{16^{\circ}}=\mathrm{S}_{4^{\circ}}=\mathrm{C}\end{array}$ \\
\hline STR4b & 8 & $\begin{aligned} & p<0.001 \quad p<0.01 \\
& \mathrm{~W}_{16^{\circ}}=\mathrm{S}_{4^{\circ}}>\mathrm{S}_{16^{\circ}}=\mathrm{A}_{16^{\circ}}>\mathrm{C}\end{aligned}$ \\
\hline STR5 & 16 & $\begin{array}{l}p<0.001 \quad p<0.05 \\
\mathrm{C}>\mathrm{S}_{4^{\circ}}=\mathrm{W}_{16^{\circ}}>\mathrm{A}_{16^{\circ}}=\mathrm{S}_{16^{\circ}}\end{array}$ \\
\hline
\end{tabular}

$\mathrm{n}=$ Number of neurons

not by moving bars $\left(\mathrm{W}_{16^{\circ}}\right.$ or $\left.\mathrm{A}_{16^{\circ}}\right): \mathrm{S}_{16^{\circ}}=\mathrm{S}_{4^{\circ}}>\mathrm{A}_{16^{\circ}}=\mathrm{W}_{16^{\circ}}=$ C (fig. 4, 7; table 2). About $66 \%$ of the neurons responded to the moving JT. Directional sensitivities to nasotemporal or temporonasal movements were not observed. Brisk changes of the diffuse illumination led to a short increase in the discharge rate; the sensitivity to OFF was stronger than to ON. The ERF of the neurons encompassed the entire visual field of both eyes. Three neurons were activated by LFB stimulation with long latencies that varied between 12 and $23 \mathrm{msec}$. Seven neurons showed short stable latencies; 4 of these satisfied the collision criterion: $\mathrm{C}_{\mathrm{E}}=5.8 \pm$ 0.6 at $\mathrm{L}=1.6 \pm 0.2$ and $\mathrm{R}=4.7 \pm 0.4$ (table 1 ; an example is shown in fig. 8Ac).

\section{STR4 Neurons}

Neurons $(n=14)$ of this group displayed very weak or no resting discharge activity. Two types of feature sensitivity to moving stimuli were observed.

STR4a neurons $(n=6)$ responded preferably to "threatening' stimuli, specifically the large moving square $\left(\mathrm{S}_{16^{\circ}}\right)$ and the bar oriented perpendicularly to the direction of movement $\left(\mathrm{A}_{16^{\circ}}\right): \mathrm{S}_{16^{\circ}}=\mathrm{A}_{16^{\circ}}>\mathrm{W}_{16^{\circ}}=\mathrm{S}_{4^{\circ}}=\mathrm{C}$ (fig. 7; table 2). The moving JT elicited strong responses, but no directional sensitivity was observed. To changes in the diffuse light, the response to OFF was stronger than to ON. The ERF encompassed the entire visual field of the contralateral eye or both eyes. LFB stimulation elicited no responses in these neurons.

STR4b neurons $(n=8)$, unlike STR4a, were preferentially responsive to 'preylike' stimuli, that is the bar oriented 
Fig. 4. Neuron of group STR3 whose resting discharge rate was increased by moving compact $\left(\mathrm{S}_{16^{\circ}}\right.$ or $\left.\mathrm{S}_{4^{\circ}}\right)$ stimuli, but not by configurational $\left(\mathrm{W}_{16^{\circ}}\right.$ or $\left.\mathrm{A}_{16^{\circ}}\right)$ stimuli; bin width: $0.5 \mathrm{sec}$.

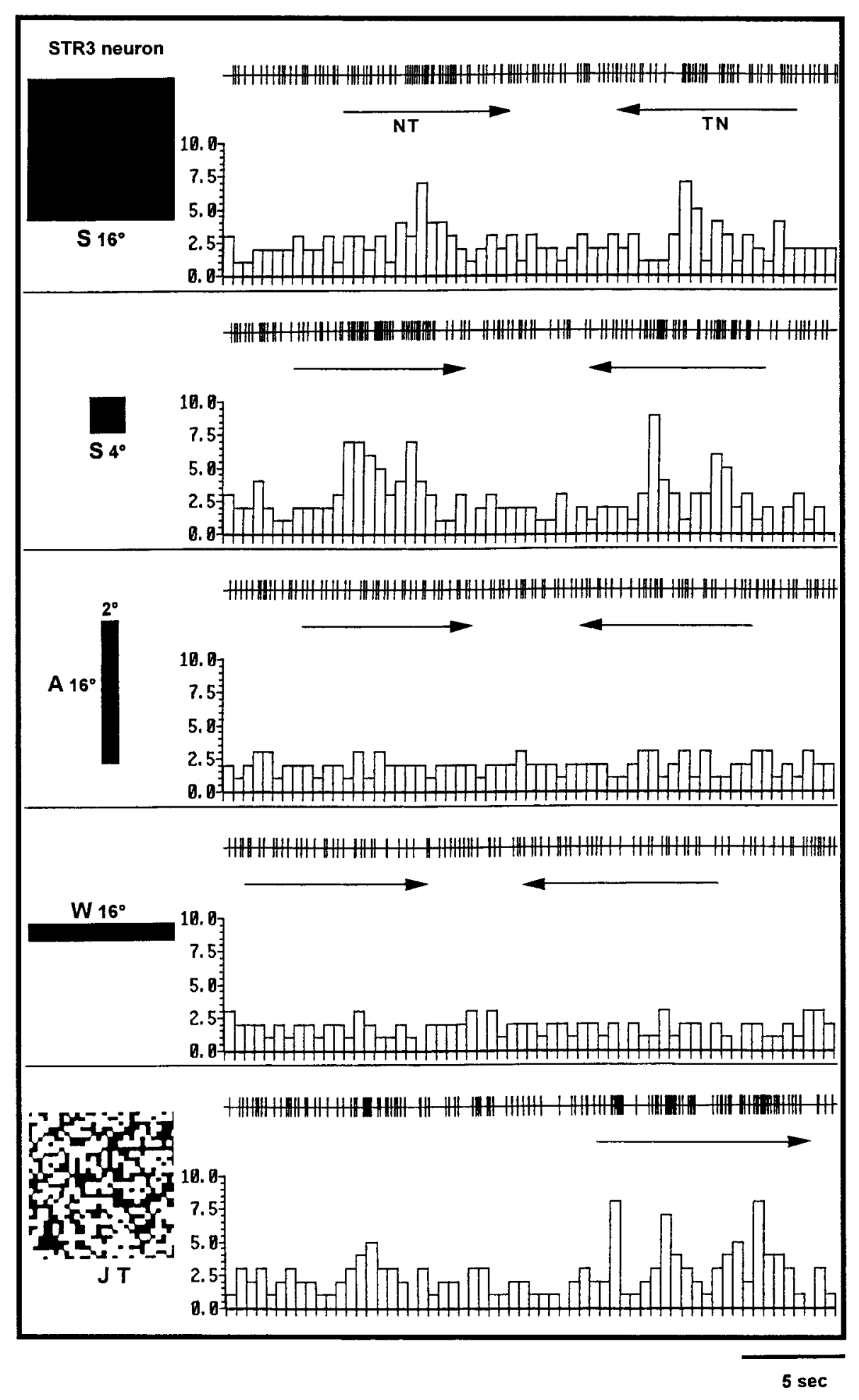

Visual Responses of Neurons Recorded in 


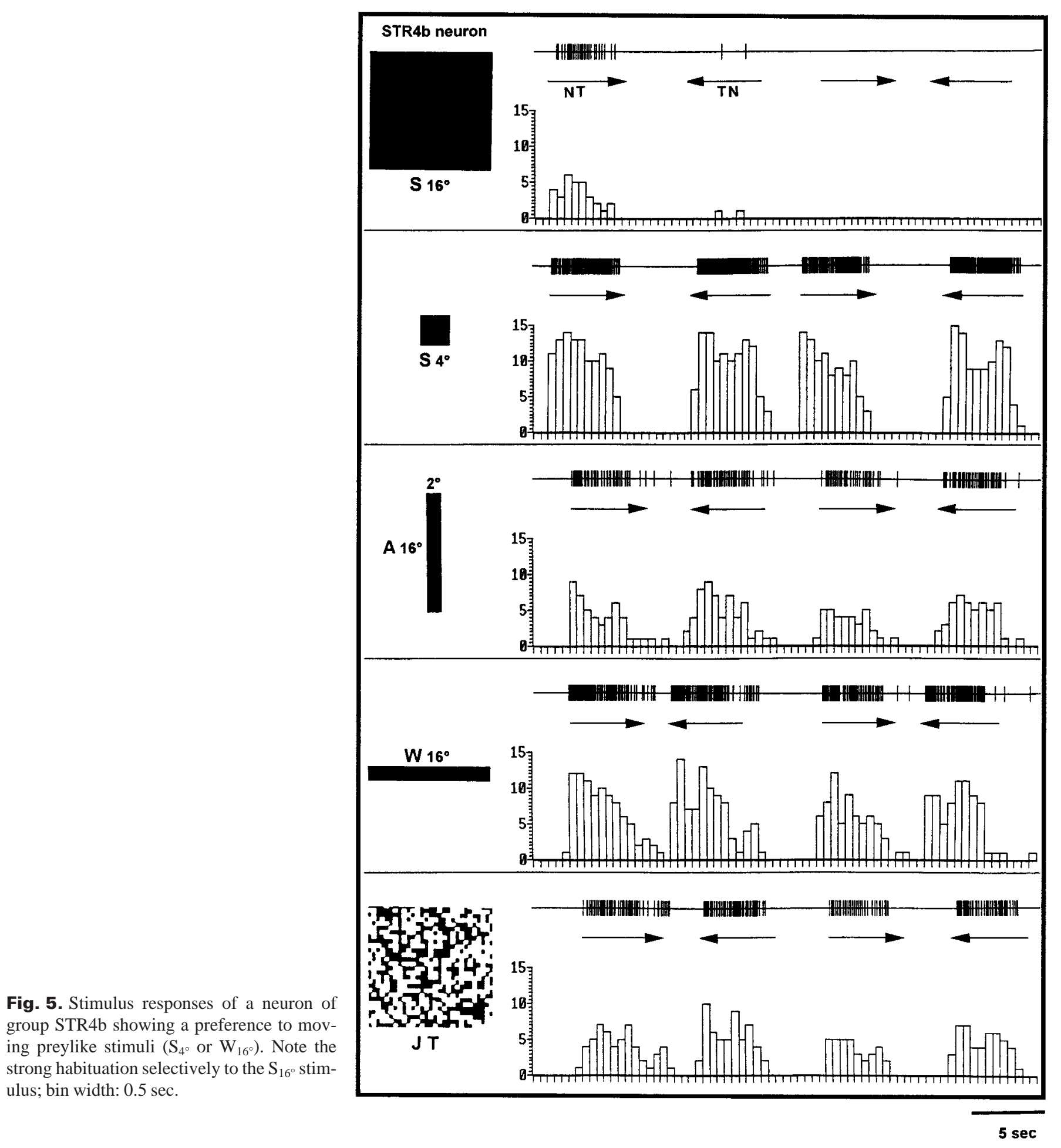


Fig. 6. Resting discharges of a STR 5 neuron whose firing rate was strongly reduced by moving threatening stimuli $\left(\mathrm{S}_{16^{\circ}}\right.$ or $\left.\mathrm{A}_{16^{\circ}}\right)$, but weakly influenced by preylike stimuli $\left(\mathrm{S}_{4^{\circ}}\right.$ or $\mathrm{W}_{16^{\circ}}$; bin width: $0.5 \mathrm{sec}$.

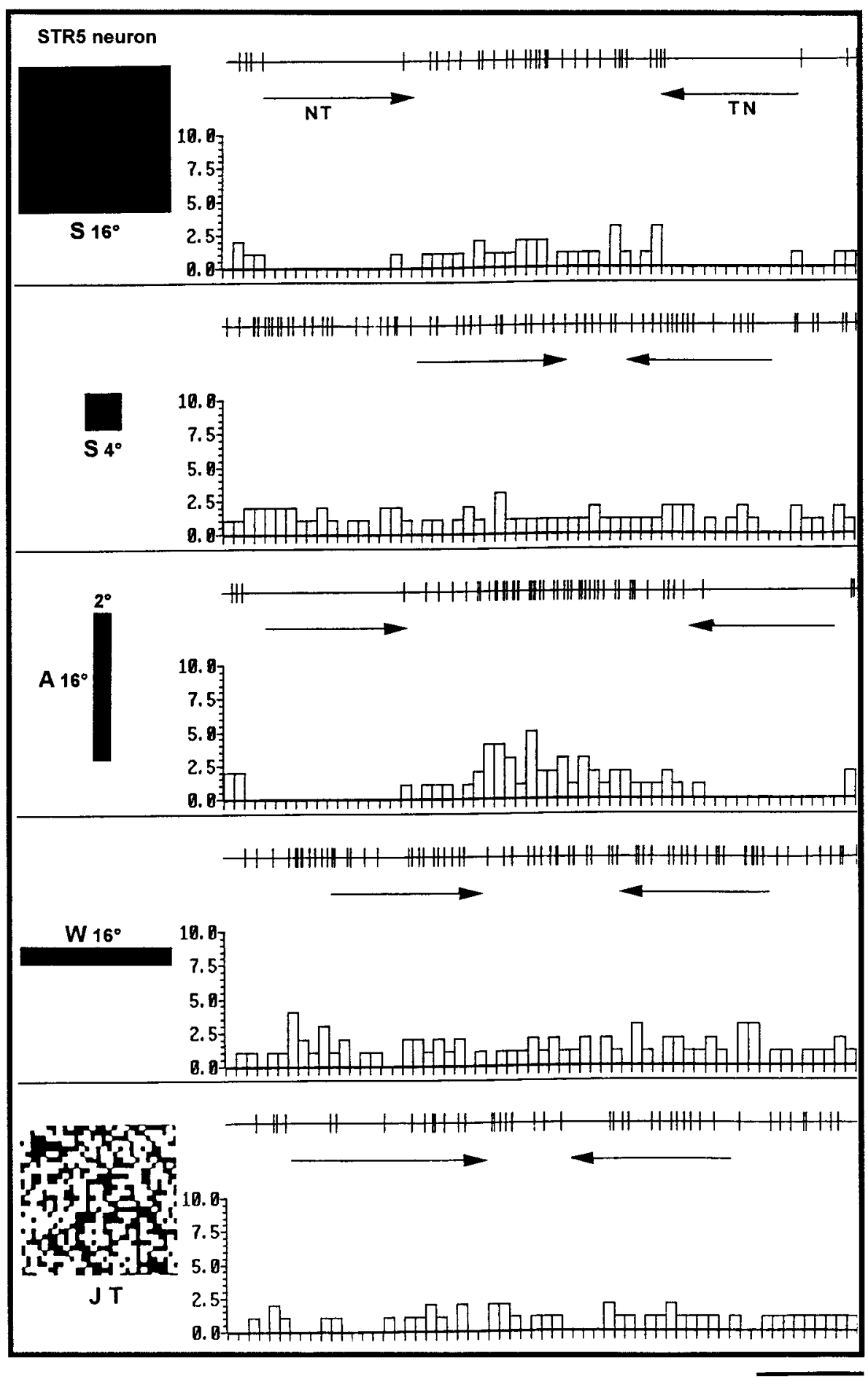

5 sec 


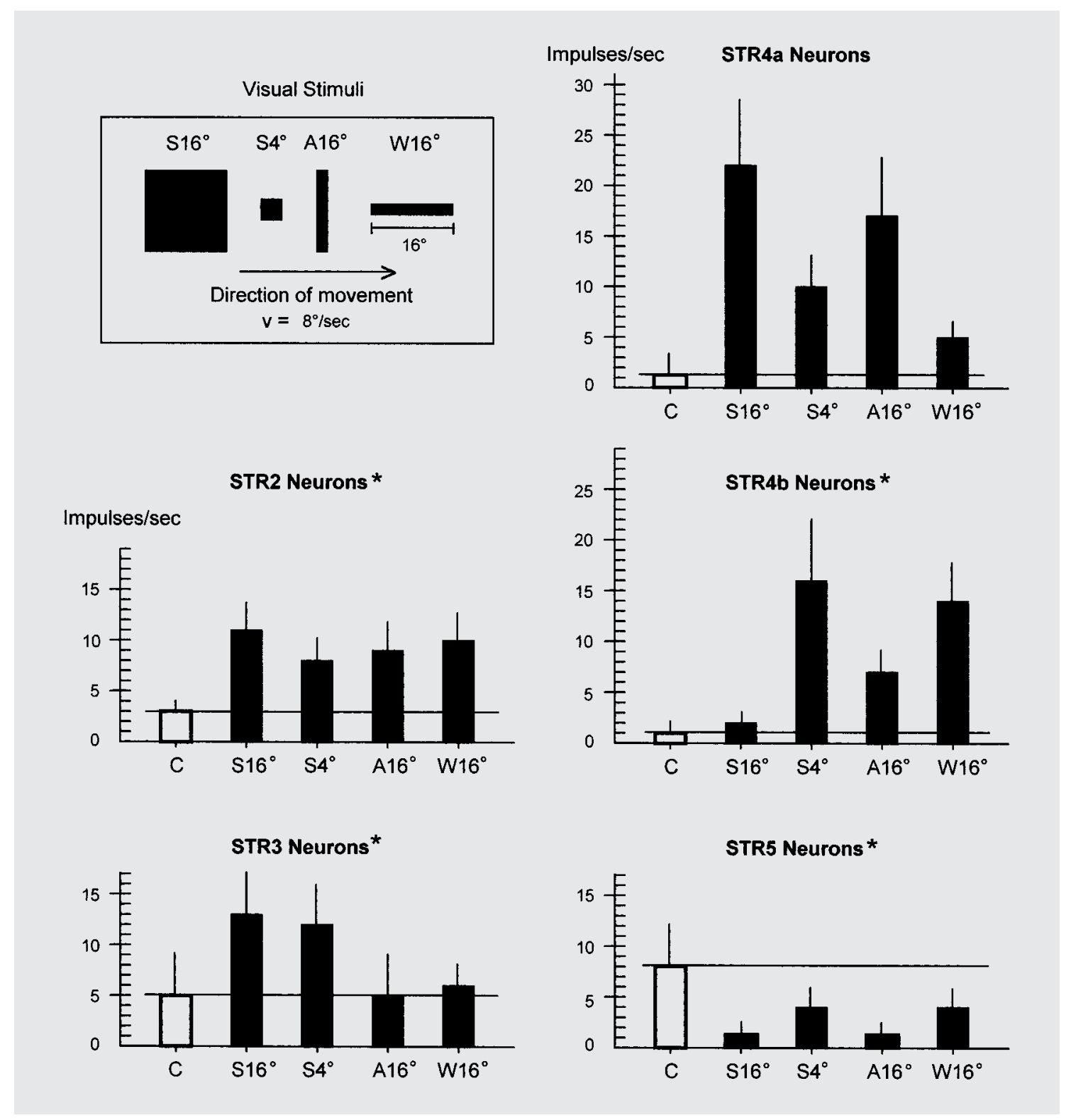

Fig. 7. Quantitative analysis of the average responses $( \pm \mathrm{SDM})$ of neurons of the groups $\mathrm{STR} 2-5$ to different configurational moving stimuli $\left(\mathrm{S}_{4^{\circ}}, \mathrm{S}_{16^{\circ}}, \mathrm{W}_{16^{\circ}}\right.$, or $\left.\mathrm{A}_{16^{\circ}}\right)$ and to the control (C). The asterisk indicates that the sample contains striatal neurons showing antidromic responses to LFB stimulation at diencephalic level.

parallel to the direction of movement $\left(\mathrm{W}_{16^{\circ}}\right)$ or the moving small square $\left(\mathrm{S}_{4^{\circ}}\right): \mathrm{W}_{16^{\circ}}=\mathrm{S}_{4^{\circ}}>\mathrm{S}_{16^{\circ}}=\mathrm{A}_{16^{\circ}}>\mathrm{C}$ (fig. 5,7 ; table 2). With repetitive stimulation, the responses of these neurons habituated selectively to the $\mathrm{S}_{16^{\circ}}$ stimulus (see fig. 5, top). The moving JT elicited moderate responses, but directional sensitivity was not observed. To changes in the diffuse light, the response to OFF was stronger than to ON. The ERF encompassed the entire visual field of both eyes. When the LFB was stimulated, 2 neurons responded at long latencies of 14-17 msec; 2 other neurons showed latencies that were short and stable, one cell satisfied the collision criterion: $C_{E}=4.0 \mathrm{msec}$ at $\mathrm{L}=1.5 \mathrm{msec}$ and $\mathrm{R}=2.6 \mathrm{msec}$ (table 1).

\section{STR5 Neurons}

These neurons $(\mathrm{n}=16)$ showed resting discharge rates that were inhibited by certain visual stimuli. In 13 neurons, the resting activity was strongly reduced by the movement 
a

A

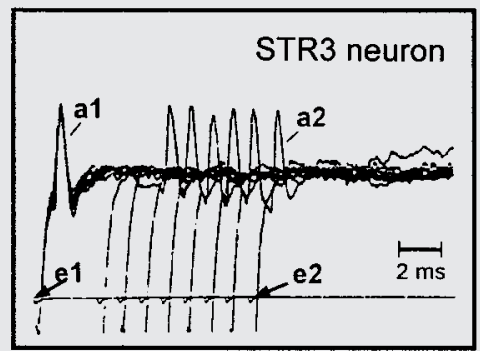

B

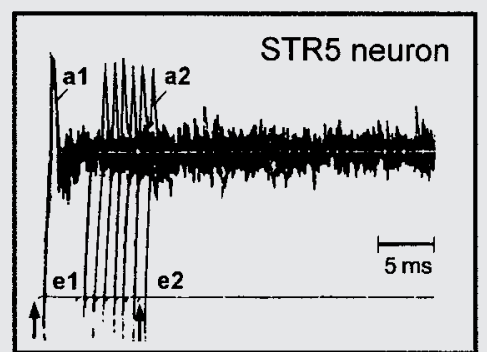

C

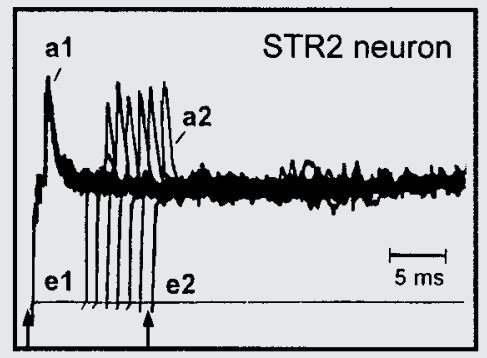

b
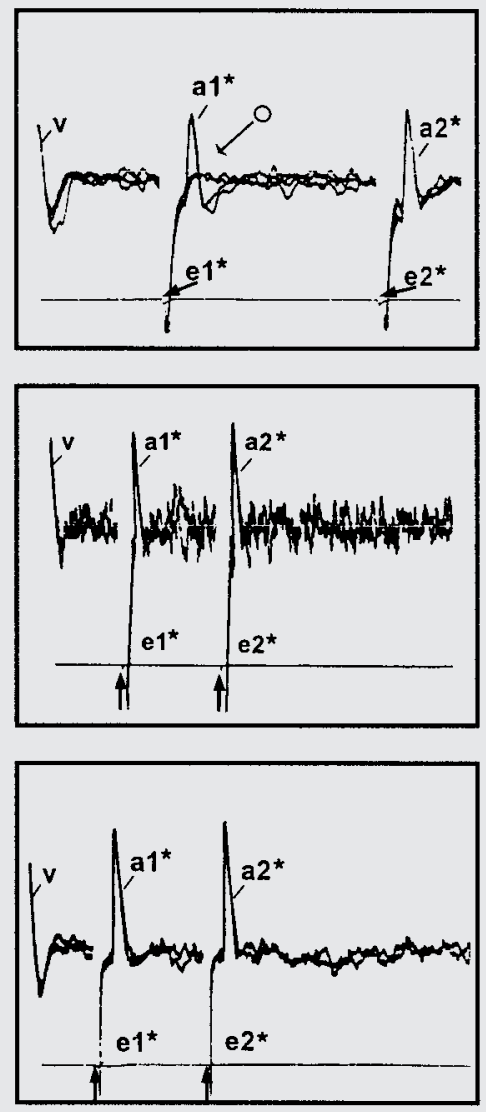

C
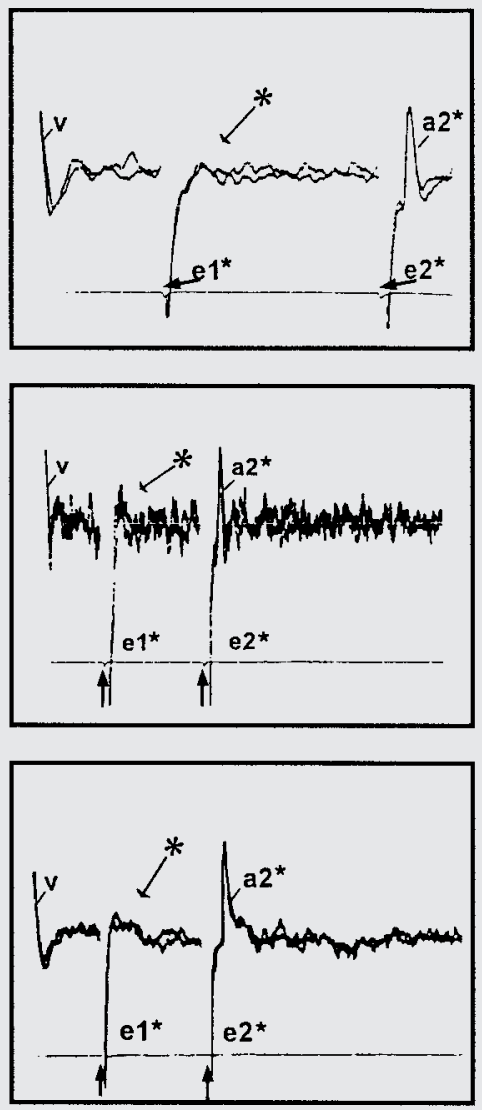

Fig. 8. Investigation of efferent projections of neurons recorded in the striatum (examples) by their antidromic activation in response to electrical stimuli e1 and e2 applied to the ipsilateral LFB in the rostral diencephalon. Pictures of the recordings were taken from the screen of a storage oscilloscope. A Neuron of group STR3. a Procedure to determine the constant latency $(\mathrm{L})$ and the absolute refractory period $(\mathrm{R}) ; \mathrm{L}=1.5 \mathrm{msec} ; \mathrm{R}=5.2 \mathrm{msec}$. To determine the absolute refractory period, antidromic spikes a 1 and a2 were elicited by the stimuli e 1 and e2. Note that $\mathrm{e} 2$ followed e 1 after a variable interval, in this case 8 different intervals are shown (superimposed records). The onsets of the stimuli (e.g. indicated by the arrows) are marked by the tiny distortions in the lower trace. The arrow assigned to stimulus e2 in this figure points to the largest interstimulus interval. Two a 2 spikes are missing because the corresponding e 2 stimuli were applied during the neuron's refractory period. b, $\mathbf{c}$ Collision test. In $\mathbf{b}$ the visually elicited spike $\mathrm{v}$ triggered two electrical stimuli e1*-e $2 *$; both electrical stimuli were separated by a constant interval $(>2 \mathrm{R})$. Each stimulus elicited an antidromic spike a $1 *$ and $a 2^{*}$, respectively. At a critical delay between $\mathrm{v}$ and $\mathrm{e} 1 *$, spike a ${ }^{*}$ was extinguished (see arrow with small circle) but not a2 (serving as control). This case illustrates a threshold phenomenon: with repetitive stimulation, a ${ }^{*}$ either did occur or failed to occur (see superimposed traces), thus the v-e ${ }^{*}$ delay was at threshold level (collision threshold C $=6.5 \mathrm{~ms}$ ). In $\mathbf{c}$ the complete collision (see arrow with asterisk) is shown for $\mathrm{C}_{\mathrm{E}}=6.3 \mathrm{msec}$. B Neuron of group STR5. a Constant latency $\mathrm{L}=2.4 \mathrm{msec}$; refractory period $\mathrm{R}=4.2 \mathrm{msec}$. For the procedure to determine $\mathrm{R}$ see also $\mathbf{A a}$ : the arrow assigned to stimulus e 2 points to the largest of 7 interstimulus intervals; the e2-stimulus that was following e1 after the very short interval (during the refractory period) elicited no antidromic spike. b, $\mathbf{c}$ Collision test: in $\mathbf{b}$ there was no collision at a delay of $C=6.6 \mathrm{msec}$; in $\mathbf{c}$ collision occurred at $\mathrm{C}_{\mathrm{E}}=6.2 \mathrm{msec}$ ( $\mathrm{see}$ arrow with asterisk). $\mathbf{C}$ Neuron of group STR2. a Constant latency $\mathrm{L}=2.4 \mathrm{msec}$; refractory period $\mathrm{R}=4.2 \mathrm{msec}$. Procedure to determine $\mathrm{R}$ see also Aa: the arrow assigned to stimulus e 2 points to the largest of 7 interstimulus intervals; the e2-stimulus that followed e1 after the very short interval (during the refractory period) elicited no antidromic spike. b, c Collision test: in $\mathbf{b}$ there was no collision at a delay of $\mathrm{C}=6.5 \mathrm{msec}$; in $\mathbf{b}$ collision occurred at $\mathrm{C}_{\mathrm{E}}=6.2 \mathrm{msec}$ (see arrow with asterisk). Calibration bar: $2 \mathrm{msec}(\mathbf{A}), 5 \mathrm{msec}(\mathbf{B}, \mathbf{C})$. 
of threatening stimuli $\left(\mathrm{S}_{16^{\circ}}\right.$ or $\left.\mathrm{A}_{16^{\circ}}\right)$, however, these neurons were weaker influenced by moving preylike stimuli $\left(\mathrm{S}_{4}\right.$ 。 or $\mathrm{W}_{16^{\circ}}$ ): $\mathrm{C}>\mathrm{S}_{4^{\circ}}=\mathrm{W}_{16^{\circ}}>\mathrm{A}_{16^{\circ}}=\mathrm{S}_{16^{\circ}}$ (fig. 6, 7; table 2). The moving JT showed no influence on the discharge rate. No directional sensitivity was observed and the discharge rate was not altered by changes in the diffuse light. The receptive field encompassed the entire field of vision of both eyes. In the condition of LFB stimulation, 2 neurons responded at long latencies of 11-24 msec; 5 neurons displayed short, stable latencies, 2 neurons satisfied the collision criterion for $\mathrm{C}_{\mathrm{E}}=7.4[6.2] \mathrm{msec}$ at $\mathrm{L}=2.3[2.4] \mathrm{msec}$ and $\mathrm{R}=5.6[4.2] \mathrm{msec}$ (table 1 ; an example is shown in fig. $8 \mathrm{Bc}$ ).

In three neurons the resting activity of 5-12 spikes/sec was uninfluenced by moving stimuli, but the resting activity was inhibited for 2-4 sec after dimming the visual field. The receptive fields covered the entire field of vision of both eyes. LFB stimulation elicited no response.

\section{Neurons Not Assigned to Groups}

The responses of 24 neurons habituated so quickly that their characteristics to the test stimuli could not be determined quantitatively.

\section{Histological Reconstruction of Recording Sites}

Figure $2 \mathrm{Ca}-\mathrm{c}$ shows examples of the recording sites of the visually sensitive neurons of the groups STR2 to STR5. We found the sites mainly in the central grey of the ventral caudal striatum involving an area of the striatal neuropil and the LFB at telencephalic level. In the present sample, there was no correlation between neurons assigned to the five groups and the recording sites.

\section{Discussion}

Reports on the visual response properties of telencephalic neurons in amphibians are scarce. Karamian et al. [1966] recorded slow-wave potentials in the frog's medial pallium ('primordium hippocampi') evoked by electrical stimulation of the optic nerve or the thalamus. Trepakov [1974] found postsynaptic inhibition in the medial pallium. Liege and Galand [1972] recording from the frog's posterior telencephalon found visually sensitive, wide-field neurons which were inhibited by darkness (comparable to some neurons of group STR5 of the present study). Gruberg and Ambros [1974] also described large receptive fields in the frog's striatum neurons that responded to ON of light, and were inhibited transiently by the OFF of light. Furthermore, neurons were described in which small moving objects elicited maximal responses (resembling properties of neurons of group STR4b). It was also reported by Gruberg and Ambros [1974] that many neurons recorded in the striatum display strong habituation to repetitive visual stimulation (resembling properties of STR4b neurons and of the 24 neurons not assigned to groups).

In the present study, we quantitatively describe visual response properties of neurons recorded in the striatum and check their efferent projections into the LFB.

\section{Critical Evaluation of the Stimulation and \\ Recording Sites}

A goal of this investigation was the backfiring of visually sensitive neurons recorded in the striatum whose axons descend in the LFB. The electrical stimuli were applied to the LFB at the diencephalic level. Cells were recorded at caudal striatal levels through which the LFB is traveling. One might argue that there is some uncertainty in where exactly the stimulating and/or recording electrodes were placed and the exact identity of the neurons we were stimulating or recording. For example, given the relatively wide spacing (less than $500 \mu \mathrm{m}$, cf. fig. 2B) of the bipolar stimulating electrodes - one electrode touching the LFB on its left side and the other on the right side - we address the question of whether these electrodes also stimulated diencephalic structures adjacent to the LFB. Threshold currents were less than $15 \mu \mathrm{A}$. In fact, Bagshaw and Evans [1976], measuring current spread from microelectrodes while stimulating nervous tissue, mention that with monopolar stimulation at a current of $10 \mu \mathrm{A}$ there is current spread of $150 \mu \mathrm{m}$. However, with bipolar stimulation the current density is highest between the two electrodes. Furthermore, bipolar stimulation has an advantage in that the effective current spread is asymmetrical: if diencephalic structures close to the LFB were stimulated due to current spread after reversing the stimulation polarity - which we usually applied - other diencephalic structures were stimulated by a different current spread. Because the same neuron recorded in the striatum usually showed the constant low latency response (and the collision phenomenon in the cases studied) with either stimulation polarity, it is highly probable that this neuron was activated by stimuli applied to the tissue between the pair of electrodes, i.e. the area in which the LFB is travelling.

Furthermore, we tested stimulus currents of different strengths which is a better strategy than routinely applying strong stimuli for two reasons [Fuller and Schlag, 1976]: (1) to obtain an axon as close as possible in the area of highest current density, we usually used the weakest possible stimulus current in order to activate the corresponding stri- 
atal cell antidromically. (2) Because the effective strength of a stimulus current is relative to the proximity of the axon, a stimulus of a low threshold current will barely be strong enough to excite more distant axons outside the area between both stimulation electrodes.

The other critical point concerns the recording sites in the caudal ventral striatum. How do we know what cells we have recorded? This problem would not exist with combined intracellular recording and labeling techniques that, however, were not used in this study. We applied extracellular recording because the neuronal responses from the striatal region could be more easily detected with the chosen metal electrodes rather than with micropipettes. Figure $2 \mathrm{C}$ shows examples of 40 recording sites projected onto three brain transverse sections. This illustration indicates that it was not our purpose to quantitatively determine spatial sample distributions, but rather to check recording sites in the striatal region that were responsive to visual stimulation and to electrical stimuli applied to the LFB in the diencephalon. Therefore, figure $2 \mathrm{Ca}-\mathrm{c}$ should not imply that visually driven cells in the striatal neuropil were found to be equally distributed as seen in the striatal central grey.

At a first glance, however, it seems hard to understand that many of the electrodes were not only located in the striatal central grey region, but also lateral to it in its neuropil. Is there any justification that action potentials recorded from 'white matter' can represent impulses from striatal efferent cells, rather than from fibers of passage? The possibility that some of the recordings were from axons passing through the striatum can never be completely eliminated when extracellular recordings are made. However, there is anatomical and physiological evidence supporting the existence of cells and cell responses in the so-called white matter region lateral to the striatal grey:

(1) Klüver Barrera-stained transverse sections of the cane toad's (Bufo marinus) caudal telencephalon clearly show that the striatal neuropil is not cell free, but rather it contains scattered cell bodies (fig. 2Cb). Lázár and Kozicz [1990], too, found such cells in the striatal neuropil in Nisslstained brain sections of the frog (Rana esculenta); some cells even formed a vaguely defined plate.

(2) Marking 15 recording sites of striatal light-ON/OFF units by means of small electrolytic lesions in Rana pipiens, Gruberg and Ambros [1974] report that these areas were located in the caudal striatal grey or the adjacent LFB.

(3) Injecting CLC (cobaltous lysine complex) into the LFB at the diencephalic level in Rana esculenta, Lázár and Kozicz [1990] showed retrogradely filled cells both in the dorsal striatum and the striatal neuropil lateral to the adjacent LFB. Most backfilled cells were found in the central grey of the ventral striatum; however, the authors emphasize that an unusually large neuron in the striatal neuropil was labeled also.

(4) Placing HRP (horseradish peroxidase) in the pretectum of Rana pipiens, Wilczynski and Northcutt [1983a] found backfilled telencephalic cells not only in the ipsilateral ventral and caudal portions of the striatum cell plate, but also many larger cells embedded in the striatal neuropil were also filled. After tegmental HRP injections, most HRPpositive cells were located throughout the length of the caudal striatum, but the large cells in the caudal striatal neuropil which concentrated HRP following the pretectal HRP injection were not filled. This suggests that axons descending from striatal cells localized in the striatal neuropil have specific destinations.

(5) After application of the retrograde tracers BDA (biotinylated dextran amine) or FDA (fluorescein-conjugated dextran amine) to the optic tectum of Rana perezi, Marín et al. [1997a] illustrated examples of retrogradely labelled cells in the caudal ventral striatum; some backfilled cells were localized in the striatal central grey, but cells were also found in the striatal neuropil.

\section{Neural Properties and Sample Frequencies}

The characterization of neurons recorded in the striatum refers only to the visual test stimuli applied in this investigation. We cannot extend the results of this study to auditory, vibratory, or tactile striatal sensitivities. Of the 128 neurons recorded, 104 neurons are assigned to five groups based on their visual response characteristics:

STR1 neurons $(24.0 \%)$ showed different patterns of resting discharges that were uninfluenced by the visual test stimuli. STR2 neurons $(31.7 \%)$ responded to anything moving, independently of object size or configuration and thus behaved like 'motion detectors'. STR3 neurons (15.4\%) preferred compact (square) objects, thus behaving like 'compact object perceivers'. STR4 neurons (13.5\%) revealed different sensitivities to configurational (bar) stimuli; type STR4a responded well to threatening stimuli, and type STR4b preferred preylike objects. In STR5 neurons (15.4\%), the resting discharge activities were reduced by visual stimuli, especially those stimuli associated with threat. Among the visually sensitive neurons, the STR2 'motion detectors' (42\%) represent the main response type.

The receptive fields of the neurons recorded in the striatum encompassed the visual field of the contralateral eye $(46 \%)$ or the entire field of vision of both eyes $(54 \%)$. Changes in the direction of movement of a visual stimulus (i.e. nasotemporal or temporonasal) did not influence their firing rates. Very strong habituation to repetitive visual stim- 
ulation was observed in the 24 neurons that could not be assigned to groups. STR4b neurons showed stimulus-selective habituation.

We also examined the striatal afferents and efferents mediated via LFB. We note that $34 \%$ of the neurons recorded in the striatum responded to ipsilateral LFB stimulation (table 1). Of these neurons, $40 \%$ were driven polysynaptically, 20\% could be afferent fiber terminals (e.g. of diencephalic cells), whereas $40 \%$ of the LFB stimulus-activated cells satisfied the collision test which suggests that they projected their axons caudally through the LFB. In the present study the main striatal output via ipsilateral LFB is mediated by 'motion detectors' (STR2) and 'compact object perceivers' (STR3). These cells were recorded in the caudal ventral striatum involving an area close to the LFB. This location is consistent with neuroanatomical data by Wilczynski and Northcutt [1983b] who showed that the greatest share of efferent striatal neurons is found in the ventral striatum. Lázár and Kozicz [1990] described four morphologically distinct types of striatal cells projecting in the ipsilateral LFB; piriform and pyramidal cells (majority) and fusiform and multipolar cells (minority).

Because of possible problems with antidromic investigations due to pecularities in the morphological and electrophysiological cell properties [Fuller and Schlag, 1976; Lipski, 1981], the number of suggested efferent striatal neurons is probably underestimated in the present study. Nevertheless, a reasonable proportion of recorded cells might also be involved in striatal intrinsic processing. Furthermore, the striatum communicates directly with other telencephalic structures such as the lateral amygdala [Wilczynski and Northcutt, 1983a, b], the lateral pallium [Hoffmann, 1973; Wilczynski and Northcutt, 1983b], and the anterior entopeduncular nucleus [Wilczynski and Northcutt, 1983a, b; Marín et al., 1997a].

\section{Some Suggested Functions of Striatal Efferent Neurons}

We emphasize that $40 \%$ of the neurons responding to LFB stimulation were determined to be striatal efferents (collision criterion, see table 1), so that this study as a whole should not imply that all the neurons recorded in the striatum are influencing the optic tectum either directly or indirectly. In investigating how the anuran optic tectum might be influenced by the striatum, we note a direct striato-tectal pathway [Marín et al., 1997a, c] comparable to the one shown in urodeles [Finkenstädt et al., 1983; Marín et al., 1997a]. Apart from this direct projection, three indirect connections were observed: a striato-pretecto-tectal pathway, a striato-tegmento-tectal pathway, and a striato-pallido-pretecto-tectal pathway [summarized by Marín et al., 1997a, 1998b]. Thus, the striatal visual efferents, as determined in the present study, could be acting via four different pathways.

The physiological characteristics of the striato-pretectotectal disynaptic pathway offer an interesting perspective on experimentally tested neuroethological data. In studies applying the ${ }^{14} \mathrm{C}$-2-deoxyglucose technique it was shown that visually elicited prey-catching orienting activity in toads leads to an increase in glucose utilization in both the caudal ventral striatum and the optic tectum, whereas the pretectal lateral posterodorsal thalamic nucleus showed a decrease in glucose utilization [Finkenstädt et al., 1985, 1986; see also Finkenstädt and Ewert, 1985]. We suggest that stimulating striato-pretecto-tectal influences are mediated by disinhibition, that is by double inhibition involving an inhibitory striato-pretectal and an inhibitory pretecto-tectal route [Ewert, 1987, 1997; Ewert et al., 1999; see also Glagow and Ewert, 1999]. This is consistent with lesion studies: after telencephalic ablation or striatal lesions, pretecto-tectal inhibition overrides the tectal prey-catching release system, which explains visual prey neglect [Ewert, 1967; Finkenstädt, 1989; Patton and Grobstein, 1998a, b]. After pretectal lesions, the pretecto-tectal inhibition fails to occur and the tectal preycatching releasing system is disinhibited [Ewert 1968, 1984; inhibitory striato-pretectal influences are suggested by: Lázár and Kozicz, 1990; Matsumoto et al., 1991; Marín et al., 1997c; for pretecto-tectal inhibitory influences see: Ewert, 1968, 1987; Ingle, 1983; Kondrashev, 1987; Merchenthaler et al., 1989; González and Smeets, 1991; Lázár et al., 1993; Kozicz and Lázár, 1994; Chapman and Debski, 1995; Buxbaum-Conradi and Ewert, 1995; Schwippert and Ewert, 1995; Schwippert et al., 1995, 1998; Ewert et al., 1996; Glagow and Ewert, 1999].

One of the questions that initiated the present study concerned the type of information that leaves the striatum (cf. fig. 7). We focus on striatal outputs that send steady streams of impulses that can be modulated up or down depending on the motion of any visual stimulus (STR2 cells), or its shape and movement (STR3 and STR5 cells). Another type of striatal output shows responses mainly to preylike moving objects (STR4b cells). These differences in the response properties of striatal neurons suggest several scenarios mediated by the disinhibitory striato-pretecto-tectal pathway (fig. 7).

(1) The 'motion detector' channel mediated by STR2 cells might generally arouse the neurons responsible for movements triggered in the tectum. For example, by reducing the pretecto-tectal inhibition if an object traverses the visual field, it would raise the attention and thus allow the translation of perception into action. 
(2) Tecto-motor responses can be modulated to compact stimuli by STR3 neurons or to preylike objects by STR4b neurons.

(3) The resting discharge activity of STR5 neurons could adjust a response readiness for prey-catching in the tectum. If, however, a threatening $\left(\mathrm{A}_{16^{\circ}}\right.$ or $\left.\mathrm{S}_{16^{\circ}}\right)$ stimulus traverses the field of vision, the resting activity in STR5 neurons is reduced and this - via the disinhibitory striato-pretecto-tectal pathway - might increase the trigger-threshold of preycatching behavior.

We emphasize that the response properties of the toad's striatal neurons must be also considered, for example, in a striato-tegmento(nigro)-tectal pathway [Wilczynski and Northcutt, 1983b; Lázár and Kozicz, 1990; Marín et al., 1998b]. Other visual functions of the anuran striatum in addition to those mentioned here must also be considered (e.g. see Ingle, 1991).

\section{Acknowledgments}

We thank anonymous referees for their constructive suggestions on the manuscript and Dr. Blinda McClelland for copy editing comments. We are grateful to Mrs. Dr. E. Schürg-Pfeiffer for the statistical analysis of the quantitative experimental data. Our thanks are also offered to Mrs. H. Hage for the photographic pictures taken from the histological brain sections and to Mrs. K. Große-Mohr, Mrs. C. Uthof, Mrs. G. Kaschlaw and Mrs. U. Reichert for technical assistance. This work was supported by the Bundesministerium für Bildung, Wissenschaft, Forschung und Technologie (BMBF); project carrier: Deutsche Forschungsanstalt für Luft- und Raumfahrt (DLR), Project 'SEKON' No. 413-5839-01 IN 104 C/4 (Ewert).

\section{References}

Bagshaw, E.V., and M.H. Evans (1976) Measurement of current spread from microelectrodes when stimulating within the nervous system. Exp. Brain Res., 25: 391-400.

Birkhofer, M., H. Bleckmann, and P. Görner (1994) Sensory activity in the telencephalon of the clawed toad, Xenopus laevis. Eur. J. Morphol., 2-4: 262-266.

Buxbaum-Conradi, H., and J.-P. Ewert (1995) Pretecto-tectal influences I. What the toad's pretectum tells its tectum: an antidromic stimulation/recording study. J. Comp. Physiol. A, 176: 169-180.

Chapman, A.M., and E.A. Debski (1995) Neuropeptide $\mathrm{Y}$ immunoreactivity of a projection from the lateral thalamic nucleus to the optic tectum of the leopard frog. Vis. Neurosci., 12: $1-9$.

Chevalier, G., and J.M. Deniau (1990) Disinhibition as a process in the expression of striatal function. Trends Neurosci., 13: 277-280.

Chevalier, G., S. Vacher, and J.M. Deniau (1984) Inhibitory nigral influence on tectospinal neurons, a possible implication of basal ganglia in orienting behavior. Exp. Brain Res., 53: 320 326.

Ewert, J.-P. (1967) Untersuchungen über die Anteile zentralnervöser Aktionen an der taxisspezifischen Ermüdung der Erdkröte (Bufo bufo L.). Z. vergl. Physiol., 57: 263-298.

Ewert, J.-P. (1968) Der Einfluß von Zwischenhirndefekten auf die Visuomotorik im Beute- und Fluchtverhalten der Erdkröte (Bufo bufo L.). Z. vergl. Physiol., 61: 41-70.

Ewert, J.-P. (1971) Single unit response of the toad (Bufo americanus) caudal thalamus to visual objects. Z. vergl. Physiol., 74: 81-102.

Ewert, J.-P. (1984) Tectal mechanisms that underlie prey-catching and avoidance behaviors in toads. In Comparative Neurology of the Optic Tectum (ed. by H. Vanegas), Plenum Press, New York, pp. 247-416.
Ewert, J.-P. (1987) Neuroethology of releasing mechanisms: prey-catching in toads. Behav. Brain Sci., 10: 307-405.

Ewert, J.-P. (1992) Neuroethology of an object features relating algorithm and its modification by learning. Rev. Neurosci., 3: 45-63.

Ewert, J.-P. (1997) Neural correlates of key stimulus and releasing mechanism: a case study and two concepts. Trends Neurosci., 20: 332-339.

Ewert, J.-P., and H.-W. Borchers (1971) Reaktionscharakteristik von Neuronen aus dem Tectum opticum und Subtectum der Erdkröte Bufo bufo (L.). Z. vergl. Physiol., 71: 165-189.

Ewert, J.-P., E. Schürg-Pfeiffer, and W.W. Schwippert (1996) Influence of pretectal lesions on tectal responses to visual stimulation in anurans: field potential, single neuron and behavior analyses. Acta Biol. Hung., 47: 223-245.

Ewert, J.-P., H. Buxbaum-Conradi, M. Glagow, A. Röttgen, E. Schürg-Pfeiffer, and W.W. Schwippert (1999) Forebrain and midbrain structures involved in prey-catching behaviour of toads: stimulus-response mediating circuits and their modulating loops. Eur. J. Morphol., 37: 111115.

Finkenstädt, T. (1989) Visual associative learning: searching for behaviorally relevant brain structures in toads. In Visuomotor Coordination: Amphibians, Comparisons, Models, and Robots (ed. by J.-P. Ewert and M.A. Arbib), Plenum Press, New York, pp. 799-832.

Finkenstädt, T., and J.-P. Ewert (1985) Glucose utilization in the toad's brain during anesthesia and stimulation of the ascending reticular arousal system. A ${ }^{14} \mathrm{C}$-2-deoxyglucose study. Naturwiss., $72: 161$.

Finkenstädt, T., S.O.E. Ebbesson, and J.-P. Ewert (1983) Projections to the midbrain tectum in Salamandra salamandra L. Cell Tiss. Res., 234: 39-55.
Finkenstädt, T., N.T. Adler, T.O. Allen, S.O.E. Ebbesson, and J.-P. Ewert (1985) Mapping of brain activity in mesencephalic and diencephalic structures of toads during presentation of key stimuli: a computer assisted analysis of $\left({ }^{14} \mathrm{C}\right) 2 \mathrm{DG}$ autoradiographs. J. Comp. Physiol. A, 156: 433-445.

Finkenstädt, T., N.T. Adler, T.O. Allen, and J.-P. Ewert (1986) Regional distribution of glucose utilization in the telencephalon of toads in response to configurational visual stimuli: a ${ }^{14}$ C-2DG study. J. Comp. Physiol. A, 158: $457-$ 467

Fite, K.V., and F. Scalia (1976) Central visual pathways in the frog. In The Amphibian Visual System: A Multidisciplinary Approach (ed. by K.V. Fite), Academic Press, New York, pp. 87118.

Fuller, J.H., and J.D. Schlag (1976) Determination of antidromic excitation by the collision test: problems of interpretation. Brain Res., 112: 283-298.

Glagow, M., and J.-P. Ewert (1999) Apomorphine alters prey-catching patterns in the common toad: behavioral experiments and ${ }^{14} \mathrm{C}$-2-deoxyglucose brain mapping studies. Brain Behav. Evol., 54: 223-242.

González, A., and W.J.A.J. Smeets (1991) Comparative analysis of dopamine and tyrosine hydroxylase immunoreactivities in the brain of two amphibians, the anuran Rana ridibunda and the urodele Pleurodeles waltlii. J. Comp. Neurol., 303: 457-477.

Gruberg, E.R., and V.R. Ambros (1974) A forebrain visual projection in the frog (Rana pipiens). Exp. Brain Res., 44: 187-197.

Hoffmann, A. (1973) Stereotaxis atlas of the toad's brain. Acta Anat., 84: 416-451.

Hore, J., and T. Vilis (1980) Arm movement performance during reversible basal ganglia lesions in the monkey. Exp. Brain Res., 39: 217-228. 
Ingle, D. (1983) Prey selection in frogs and toads: a neuroethological model. In Handbook of Behavioral Neurobiology, Vol. 6: Motivation (ed. by E. Satinoff and P. Teitelbaum), Plenum Press, New York, pp. 235-261.

Ingle, D. (1991) The striatum and short-term spatial memory: from frog to man. In Visual Structures and Integrated Functions (ed. by M.A. Arbib and J.-P. Ewert), Springer, Berlin, pp. 273-280.

Karamian, A.L., N.P. Vesselkin, M.G. Belekhova, and T.M. Zagorulka (1966) Electrophysiological characteristics of tectal and thalamo-cortical divisions of the visual system in lower vertebrates. J. Comp. Neurol., 127: 559-576.

Kondrashev, S.L. (1987) Neuroethology and color vision in amphibians. Behav. Brain Sci., 10: 385.

Kozicz, T., and G. Lázár (1994) The origin of tectal NPY immunopositive fibers in the frog. Brain Res., 635: 345-348.

Lázár, G. (1971) The projection of the retinal quadrants on the optic centers in the frog: a terminal degeneration study. Acta Morphol. Hung., 19: 325-334.

Lázár, G., and T. Kozicz (1990) Morphology of neurons and axon terminals associated with descending and ascending pathways of the lateral forebrain bundle in Rana esculenta. Cell Tissue Res., 260: 535-548.

Lázár, G., J.L. Maderdrut, S.L. Trasti, Z. Liposits, P. Tóth, T. Kozicz, and I. Merchenthaler (1993) Distribution of proneuropeptide Y-derived peptides in the brain of Rana esculenta and Xenopus laevis. J. Comp. Neurol., 327: 551571.

Liege, B., and G. Galand (1972) Single unit visual responses in the frog's brain. Vis. Res., 12: 609-622.

Lipski, J. (1981) Antidromic activation of neurons as an analytic tool in the study of the central nervous system. J. Neurosci. Methods, 4: 1-32.

Marín, O., A. González, and W.J.A.J. Smeets (1997a) Anatomical substrate of amphibian basal ganglia involvement in visuomotor behaviour. Eur. J. Neurosci., 9: 2100-2109.

Marín, O., A. González, and W.J.A.J. Smeets (1997b) Basal ganglia organization in amphibians: afferent connections to the striatum and the nucleus accumbens. J. Comp. Neurol., 378: 16-49.

Marín, O., A. González, and W.J.A.J. Smeets (1997c) Basal ganglia organization in amphibians: efferent connections of the striatum and the nucleus accumbens. J. Comp. Neurol., 380: $23-50$.
Marín, O., W.J.A.J. Smeets, and A. González (1997d) Basal ganglia organization in amphibians: catecholaminergic innervation of the striatum and the nucleus accumbens. J. Comp. Neurol., 378: 50-69.

Marín, O., W.J.A.J. Smeets, and A. González (1997e) Basal ganglia organization in amphibians: development of striatal and nucleus accumbens connections with emphasis on the catecholaminergic inputs. J. Comp. Neurol., 383: 349-369.

Marín, O., A. González, and W.J.A.J. Smeets (1998a) Amphibian basal ganglia control of tectal function: a complex matter [commentary with a reply by J.-P. Ewert]. Trends Neurosci., 21: 336-337.

Marín, O., W.J.A.J. Smeets, and A. González (1998b) Evolution of the basal ganglia in tetrapods: a new perspective based on recent studies in amphibians. Trends Neurosci., 21: 487-494.

Matsumoto, N., W.W. Schwippert, T.W. Beneke, and J.-P. Ewert (1991) Forebrain-mediated control of visually guided prey-catching in toads: investigation of striato-pretectal connections with intracellular recording/labeling methods. Behav. Proc., 25: 27-40.

Merchenthaler, I., G. Lázár, and J.L. Maderdrut (1989) Distribution of proenkephalin-derived peptides in the brain of Rana esculenta. J. Comp. Neurol., 281: 23-39.

Neary, T., and R.G. Northcutt (1983) Nuclear organization of the bullfrog diencephalon. J. Comp. Neurol., 213: 262-278.

Northcutt, R.G., and E. Kicliter (1980) Organization of the amphibian telencephalon. In Comparative Neurology of the Telencenphalon (ed. by S.O.E. Ebbesson), Plenum Press, New York, pp. 203-255.

Patton, P., and P. Grobstein (1998a) The effects of telencephalic lesions on the visually mediated prey orienting behavior in the leopard frog (Rana pipiens). I. The effects of complete removal of one telencephalic lobe, with a comparison to the effect of unilateral tectal lobe lesions. Brain Behav. Evol., 51: 123-143.

Patton, P., and P. Grobstein (1998b) The effects of telencephalic lesions on the visually mediated prey orienting behavior in the leopard frog (Rana pipiens). II. The effects of limited lesions to the telencephalon. Brain Behav. Evol., 51: 144-161.
Reiner, A., S.E. Brauth, and H.J. Karten (1984) Evolution of the amniote basal ganglia. Trends Neurosci., 7: 320-325.

Schürg-Pfeiffer, E., C. Spreckelsen, and J.-P. Ewert (1993) Temporal discharge patterns of tectal and medullary neurons chronically recorded during snapping toward prey in toads Bufo bufo spinosus. J. Comp. Physiol. A, 173: 363-376.

Schwippert, W.W., and J.-P. Ewert (1995) Effect of neuropeptide-Y on tectal field potentials in the toad. Brain Res., 669: 150-152.

Schwippert, W.W., T.W. Beneke, and J.-P. Ewert (1995) Pretecto-tectal influences. II. How retinal and pretectal inputs to the toad's tectum interact: a study of electrically evoked field potentials. J. Comp. Physiol. A, 176: 181-192.

Schwippert, W.W., A. Röttgen, and J.-P. Ewert (1998) Neuropeptide Y (NPY) or fragment NPY 13-36, but not NPY 18-36, inhibit retinotectal transfer in cane toads Bufo marinus. Neurosci. Lett., 253: 33-36.

Székely, G., and G. Lázár (1976) Cellular and synaptic architecture of the optic tectum. In Frog Neurobiology (ed. by R. Llinás and W. Precht), Springer, Berlin, pp. 407-434.

Trepakov, V.V. (1974) Postsynaptic inhibition in the frog's primordial hippocampus. Neurofiziol., 5: 583-592.

Vesselkin, N.P., T.V. Ermakova, N.B. Kenigfest, and M. Goikovic (1980) The striatal connections in frog Rana temporaria: an HRP study. J. Hirnforsch., 21(4): 381-392.

Weerasuriya, A. (1989) In seach of the motor pattern generator for snapping in toads. In Visuomotor Coordination: Amphibians, Comparisons, Models, and Robots (ed. by J.-P. Ewert and M.A. Arbib), Plenum, New York, pp. 589614.

Wilczynski, W., and R.G. Northcutt (1977) Afferents to the optic tectum of the leopard frog: an HRP study. J. Comp. Neurol., 173: 219-229.

Wilczynski, W., and R.G. Northcutt (1983a) Connections of the bullfrog striatum: afferent organization. J. Comp. Neurol., 214: 321-332.

Wilczynski, W., and R.G. Northcutt (1983b) Connections of the bullfrog striatum: efferent projections. J. Comp. Neurol., 214: 333-343. 